\title{
Integrated Effects of Poultry Manure and Chemical Fertilizer on Yield, Nutrient Balance and Economics of Wetland Rice Culture
}

\author{
F Rahman ${ }^{1}$, A T M S Hossain ${ }^{2}$ and M R Islam ${ }^{3}$
}

\begin{abstract}
Field trials were conducted for two years to evaluate the integrated effect of poultry manure (PM) and chemical fertilizers on yield, nutrient balance and economics of rice at BRRI, Gazipur (AEZ-28 and land type- High Land) during Boro 2009 to T. Aman 2010. Eight treatment combinations, where PM@ 1, 2, 3 t ha-1 with IPNS (Integrated plant nutrient system) based dose and PM @ 1, 2, 3 t ha ${ }^{-1}$ with 50\% STB (soil test based) dose along with a control and 100\% STB chemical fertilizer were tested. Immediate effects of manure and fertilizer were evaluated in Boro season and residual effects were observed in the following T. Aman season. Application of PM @ 2 t ha ${ }^{-1}$ with IPNS based chemical fertilizer or PM @ $3 \mathrm{t} \mathrm{ha}^{-1}$ with $50 \%$ STB dose gave higher grain yield in Boro season. Some residual effects in the succeeding T. Aman rice were observed where PM was used @ $3 \mathrm{t} \mathrm{ha-1}$. The highest net return was obtained with $3 \mathrm{t} \mathrm{PM} \mathrm{ha-1}$ with $50 \%$ STB dose. A positive nutrient balance of phosphorus and sulfur were observed in PM and chemical fertilizer treated plots.

Key words: Poultry manure, IPNS, grain yield, nutrient balance, economics
\end{abstract}

\section{INTRODUCTION}

Poultry manure is an excellent, low cost fertilizer and is a valuable organic source of essential plant nutrients and soil amendments to improve soil quality. It contains both organic and inorganic forms of nutrients. Poultry manure (fresh or semi-decomposed) is a good source of macro and micronutrients for plants as well as a potential source of organic matter in soil (Saha et al., 2004). At present about 2 million ton poultry manure per year is produced in Bangladesh which can supply about $3 \mathrm{~kg} \mathrm{P} / \mathrm{ha} / \mathrm{yr}$ (Rijpma and Jahiruddin, 2004) and application of 2 ton poultry manure ha ${ }^{-1}$ may replace the full dose of $\mathrm{P}$ and $\mathrm{S}$ and $60 \% \mathrm{~N}$ and $\mathrm{K}$ fertilizer requirement for target yield of 5-6 t ha-1 rice (Miah et al., 2006). When organic manure was applied in conjunction with inorganic fertilizers for efficient growth for crop, declination of organic carbon was arrested (Singh et al., 2001).

Around 30 days decomposed poultry manure with $50 \%$ STB chemical fertilizer is good in terms of nutrients and grain yield of rice as well as soil health (Hossain et al., 2010). Long term fertilizer experiments involving intensive cereal based cropping systems reveal a declining trend in productivity even with the application of recommended levels of N, P and K fertilizer (Mahajan et al., 2002; Mahajan and Sharma, 2005). Without adequate and balanced use of chemical fertilizers and with little or no manure have caused severe fertility deterioration.

Combined use of chemical and organic fertilizer increases retentions and improves nutrient availability. High analysis fertilizers have low contents of micronutrients, but combined use with organic manure makes these nutrients available to plants. Fixation of $P$ could be reduced and effectiveness of $K$ can be increased when chemical fertilizer is combined with organic manures. All crops can be benefited from poultry litter but it should not be applied to soil beyond the limits of the growing crops nutrient needs. This will ensure efficient use of manure nutrients and minimize 
nutrient leaching or run off into the surface and ground water system. Fertilizer recommendations based on soil test results are the only reliable way to determine the crop requirement. Soil testing, manure analysis and proper estimation of yield goal are necessary to calculate proper agronomic application rates of manure.

Now it is the demand of the time to develop an integrated organic and inorganic source of nutrients for sustainable agriculture that can ensure food production with high quality and maintain soil fertility. Integrated Nutrient Management (INM) is a concept of addition of organic manure with chemical fertilizer. Integrated Plant Nutrient Systems (IPNS) is a process where total nutrient adjusted from organic and inorganic fertilizer sources to obtained maximum yield with a view to total improvement of soil health. Combined use of organic manure and chemical fertilizer results in higher return to investment and better cost-benefit ratio (Rahman et al., 2009). The integrated use of poultry manure and chemical fertilizer may increase the productivity and reduce the chemical fertilizer dose in Rice-Rice cropping pattern. So, this study was undertaken to determine the doses of poultry manure with chemical fertilizers on the basis of IPNS concept and also determine the level of poultry manure addition with $50 \%$ soil test based chemical fertilizer dose.

\section{MATERIALS AND METHODS}

Field experiments were conducted for two years at BRRI experimental farm, Gazipur during Boro 2009 to T. Aman 2010 seasons. The soil of the experimental field was clay loam in texture having $\mathrm{pH} 6.84$, organic matter $2.42 \%$, total $\mathrm{N} 0.14 \%$, available P $5.77 \mathrm{mg} \mathrm{kg}^{-1}$, exchangeable K 0.14 meq $100 \mathrm{~g}^{-1}$ soil, available $\mathrm{S} 6.6 \mathrm{mg} \mathrm{kg}^{-1}$ and available $\mathrm{Zn} 2.8 \mathrm{mg} \mathrm{kg}^{-1}$. Eight following treatments viz $\mathrm{T}_{1}=$ Absolute control (native nutrients), $\mathrm{T}_{2}=\mathrm{PM} @ 1 \mathrm{t}$ ha $\mathrm{a}^{-1}+$ IPNS based STB dose, $\mathrm{T}_{3}=\mathrm{PM} @ 2 \mathrm{t} \mathrm{ha}^{-1}+$ IPNS based STB dose, $\mathrm{T}_{4}=$ PM @ $3 \mathrm{t} \mathrm{ha}^{-1}+$ IPNS based STB dose, $\mathrm{T}_{5}=$ PM @ $1 \mathrm{t} \mathrm{ha}^{-1}+50 \%$ STB dose, $\mathrm{T}_{6}=\mathrm{PM} @ 2 \mathrm{t} \mathrm{ha}^{-1}+50 \%$ STB dose, $\mathrm{T}_{7}=\mathrm{PM} @ 3$ t ha ${ }^{-1}+50 \%$ STB dose and $\mathrm{T}_{8}=$ $100 \%$ STB dose were tested in the experiment. Thirty days semi-decomposed PM (oven dry based), one-third of $\mathrm{N}$ and the whole amount of PKS were applied at final land preparation as per treatment requirement in Boro season. The remaining two-third $\mathrm{N}$ was applied in two equal installments at 25-30 days after transplanting and at seven days before panicle initiation stage. In T. Aman, the residual effect of PM was observed and the treatment combinations were; $\mathrm{T}_{1}=$ Absolute control, $\mathrm{T}_{2}=$ Residual effect of PM @ 1 t ha ${ }^{-1}+100 \%$ STB dose, $\mathrm{T}_{3}=$ Residual effect of PM @ $2 \mathrm{t}$ ha $^{-1}$ $+100 \%$ STB dose, $\mathrm{T}_{4}=$ Residual effect of PM @ 3 t ha $^{-1}+100 \%$ STB dose, $\mathrm{T}_{5}=$ Residual effect of PM @ $1 \mathrm{t} \mathrm{ha}^{-1}+50 \%$ STB dose, $\mathrm{T}_{6}=$ Residual effect of PM @ 2 t ha ${ }^{-1}+50 \%$ STB dose, $\mathrm{T}_{7}=$ Residual effect of PM @ $3 \mathrm{t} \mathrm{ha}^{-1}+50 \%$ STB dose and $\mathrm{T}_{8}=100 \%$ STB dose. The time and method of chemical fertilizer application was same as Boro rice. In Boro season 40-day-old seedlings of BRRI dhan29 and in T. Aman 30day-old seedlings of BRRI dhan31 were transplanted. The design of the experiment was RCBD with three replications. The individual plot size was $4 \mathrm{~m} \times 4 \mathrm{~m}$. The crops were harvested at maturity from $5 \mathrm{~m}^{2}$ areas at the centre of each plot and then grain yields were recorded at $14 \%$ moisture and straw yields at oven dry basis.

Poultry manures samples as well as rice grain and straw samples of Boro and T. Aman rice were analyzed for the determination of $\mathrm{N}$, $\mathrm{P}, \mathrm{K}$ and $\mathrm{S}$ in the Soil Science Division laboratory, BRRI, Gazipur. For analyzing the $\mathrm{P}, \mathrm{K}$ and $\mathrm{S}$ content, samples were digested with di-acid mixture of nitric and perchlororic acid at the ratio 5:2 following the method described by Yoshida et al. (1976) and $\mathrm{N}$ by Micro-Kjeldahl distillation method (Yoshida, et 
al., 1976). After two years, surface $(0-15 \mathrm{~cm}$ depth) soil samples were collected and analyzed for chemical properties like organic carbon, total nitrogen, available phosphorus, exchangeable potassium, available sulfur and zinc following standard procedure. All the data were analyzed statistically with the software of Crop Stat 7.2 version.

\section{RESULTS AND DISCUSSION}

\section{Grain and straw yield}

Poultry manure application either with IPNS or STB base chemical fertilizer had positive influence on the grain yield of Boro rice (Table 1). In Boro 2009 significantly higher grain yield was obtained when poultry manure was applied @ $2 \mathrm{t} \mathrm{ha}^{-1}$ with adjusted IPNS based chemical fertilizer $\left(\mathrm{T}_{3}\right)$ and PM @ $3 \mathrm{t} \mathrm{ha}^{-1}+50 \%$ STB dose $\left(\mathrm{T}_{7}\right)$ compared to $100 \%$ STB $\left(\mathrm{T}_{8}\right)$ chemical fertilizer but in 2010, the result was insignificant. The mean grain yield ( average of two years) was $6.20 \mathrm{t} \mathrm{ha}^{-1}$ when poultry litter @ $2 \mathrm{t}$ ha $^{-1}$ with adjusted IPNS based fertilizer and PM @ $3 \mathrm{t} \mathrm{ha}^{-1}+50 \%$ STB dose while 100\% STB treatment produced the yield $5.87 \mathrm{t} \mathrm{ha}^{-1}$. About $0.3 \mathrm{t} \mathrm{ha}^{-1}$ higher average grain yield was obtained from poultry litter treated plot compared to $100 \%$ STB dose.

Both the treatments produced statistically similar yield to each other may be due to addition of similar amount of nutrients in the soil. The lowest yield was obtained from control treatment. Lidong et al. (2009) also reported significant positive effects of organic amendments on rice yield.

In T. Aman 2009, some residual effect of PM for grain yield (which was applied in Boro season) was observed (Table 1). A significant amount of residual effect of PM was observed in $T_{5}, T_{6}$ and $T_{7}$ treatments where 1,2 and $3 \mathrm{t}$ ha ${ }^{-1}$ PM with $50 \%$ chemical fertilizer was applied respectively, in the previous Boro crop but in T. Aman 2010, the residual effect was insignificant. The two years average yield from $100 \%$ NPKS was lower than those treatments where PM was applied more than $1 \mathrm{t} \mathrm{ha}^{-1}$. This result confirmed the data obtained by other experiments conducted by Soil Science Division, BRRI (Miah, 2006) and Hossain et al. (2010). Similar trend was also observed in case of straw yield production in both the years and seasons (Table 2).

Table 1. Immediate and residual effects of poultry manure and chemical fertilizer on the grain yield $\left(t a^{-1}\right)$ of rice in Boro-Fallow-T. Aman cropping pattern at BRRI, Gazipur, 2009-10.

\begin{tabular}{|c|c|c|c|c|c|c|}
\hline \multirow{2}{*}{ Treatment } & \multicolumn{3}{|c|}{ Immediate effect (Boro grain yield) } & \multicolumn{3}{|c|}{ Residual effect (T. Aman grain yield) } \\
\hline & 2009 & 2010 & Mean & 2009 & 2010 & Mean \\
\hline $\mathrm{T} 1$ & 2.53 & 2.86 & 2.70 & 2.71 & 2.54 & 2.63 \\
\hline $\mathrm{T} 2$ & 5.75 & 5.84 & 5.80 & 3.02 & 3.49 & 3.26 \\
\hline $\mathrm{T} 3$ & 6.24 & 6.15 & 6.20 & 3.17 & 3.56 & 3.37 \\
\hline $\mathrm{T} 4$ & 5.86 & 5.98 & 5.92 & 3.33 & 3.73 & 3.53 \\
\hline T5 & 5.36 & 5.72 & 5.54 & 3.34 & 3.36 & 3.35 \\
\hline T6 & 5.84 & 5.94 & 5.89 & 3.43 & 3.38 & 3.41 \\
\hline $\mathrm{T} 7$ & 6.14 & 6.25 & 6.20 & 3.46 & 3.48 & 3.47 \\
\hline $\mathrm{T} 8$ & 5.68 & 6.05 & 5.87 & 3.06 & 3.51 & 3.29 \\
\hline LSD (0.05) & 0.19 & 0.23 & & 0.27 & 0.21 & \\
\hline CV (\%) & 1.62 & 1.55 & & 2.31 & 2.16 & \\
\hline
\end{tabular}


Table 2. Immediate and residual effects of poultry manure and chemical fertilizer on the straw yield (t ha-1) of rice in Boro-Fallow-T. Aman cropping pattern at BRRI, Gazipur, 2009-10.

\begin{tabular}{llllllll}
\hline \multirow{2}{*}{ Treatment } & \multicolumn{2}{c}{ Immediate effect (Boro grain yield) } & & \multicolumn{3}{c}{ Residual effect (T. Aman grain yield) } \\
\cline { 2 - 3 } \cline { 6 - 7 } & 2009 & 2010 & Mean & & 2009 & 2010 & Mean \\
\hline T1 & 2.77 & 3.19 & 2.98 & & 3.17 & 3.33 & 3.25 \\
T2 & 6.17 & 6.34 & 6.26 & & 3.65 & 6.10 & 4.88 \\
T3 & 6.54 & 6.60 & 6.57 & & 4.47 & 6.18 & 5.33 \\
T4 & 6.65 & 6.34 & 6.50 & & 4.62 & 6.24 & 5.43 \\
T5 & 5.68 & 6.22 & 5.95 & & 3.78 & 5.33 & 4.56 \\
T6 & 6.23 & 6.37 & 6.30 & & 3.99 & 5.64 & 4.82 \\
T7 & 6.67 & 6.70 & 6.69 & & 4.01 & 5.83 & 4.92 \\
T8 & 5.93 & 6.52 & 6.23 & & 4.03 & 6.27 & 5.15 \\
LSD (0.05) & 0.16 & 0.18 & & & 0.62 & 0.38 & \\
CV (\%) & 2.54 & 2.35 & & & 2.75 & 2.62 & \\
\hline
\end{tabular}

\section{Nutrient uptake of rice}

There is wide variation in nutrient uptake influenced by different rates of poultry manure with chemical fertilizer (Table 3). The highest $\mathrm{N}$ and $\mathrm{P}$ uptake was observed in $\mathrm{T}_{4}$ treatment where PM was applied @ $3 \mathrm{t} \mathrm{ha}^{-1}$ with IPNS based inorganic fertilizers followed by treatment $T_{7}$ where PM was applied @ $3 \mathrm{t}$ ha $^{-1}$ with $50 \%$ STB dose. The present observation was similar with the earlier findings (Rahman et al., 2009). The reasons may be the higher nutrient concentration in poultry manure (Saha et al., 2004) and literatures suggest that poultry manure is a good source of P (Griffin et al., 2003). Similar trend was also observed in case of other nutrients ( $\mathrm{K}$ and $\mathrm{S}$ ) uptake by rice in both years.

\section{Apparent nutrient balance}

Apparent nutrient balance as influenced by different rates of poultry litter with chemical fertilizer was studied. In calculating apparent nutrient balance it is assumed that $30 \mathrm{~kg} \mathrm{~N}$ from irrigation water and $20 \mathrm{~kg} \mathrm{~N}$ from BNF (Biological nitrogen fixation) was considered. Assuming that Boro rice crop requires $100 \mathrm{~cm}$ water ha-1, thus the amount of $\mathrm{P}$ and $\mathrm{K}$ through irrigation water was $0.6 \mathrm{~kg}$ and $14 \mathrm{~kg}$ ha- ${ }^{-1}$ respectively.

It was observed that the apparent nutrient balance in the control plot was always negative for all the treatments since no fertilizer or PM was added to the plots. Nitrogen replenishment through different rates of poultry manure with chemical fertilizer was not enough to balance $\mathrm{N}$ removal by crops since much of the applied $\mathrm{N}$ was lost from the soil (Fig. 1). Phosphorous balance was positive in all poultry manure treated plots irrespective of chemical source. These results were similar with the findings of some earlier works (Hossain et al., 2010 ; Ali et al., 2009).

Table 3. Nitrogen, phosphorous, potassium and sulphur uptake by rice as influenced by poultry manure, T. Aman.

\begin{tabular}{c|ccc|c|c|c|c|c|c|c|c|c}
\hline \multirow{2}{*}{ Treat. } & \multicolumn{3}{|c|}{ N uptake $\left(\mathrm{kg} \mathrm{ha}^{-1}\right)$} & \multicolumn{3}{c|}{ P uptake $\left(\mathrm{kg} \mathrm{ha}^{-1}\right)$} & \multicolumn{3}{c|}{ K uptake $\left(\mathrm{kg} \mathrm{ha}^{-1}\right)$} & \multicolumn{3}{c}{ S uptake $(\mathrm{kg} / \mathrm{ha})$} \\
\cline { 2 - 13 } & 2009 & 2010 & Total & 2009 & 2010 & Total & 2009 & 2010 & Total & 2009 & 2010 & Total \\
\hline $\mathrm{T}_{1}$ & 50 & 49 & 99 & 9 & 12 & 21 & 49 & 44 & 93 & 7 & 44 & 51 \\
$\mathrm{~T}_{2}$ & 70 & 84 & 154 & 12 & 18 & 30 & 60 & 78 & 84 & 9 & 80 & 89 \\
$\mathrm{~T}_{3}$ & 87 & 90 & 177 & 14 & 18 & 32 & 72 & 82 & 154 & 10 & 82 & 92 \\
$\mathrm{~T}_{4}$ & 93 & 96 & 189 & 15 & 18 & 33 & 75 & 91 & 166 & 11 & 92 & 103 \\
$\mathrm{~T}_{5}$ & 67 & 76 & 143 & 12 & 15 & 27 & 61 & 81 & 142 & 8 & 82 & 90 \\
$\mathrm{~T}_{6}$ & 81 & 85 & 166 & 12 & 16 & 28 & 66 & 83 & 149 & 9 & 84 & 93 \\
$\mathrm{~T}_{7}$ & 84 & 93 & 177 & 13 & 17 & 30 & 69 & 79 & 148 & 9 & 77 & 86 \\
$\mathrm{~T}_{8}$ & 81 & 89 & 170 & 12 & 14 & 26 & 66 & 77 & 143 & 8 & 77 & 85 \\
LSD (0.05) & 11.29 & 10.28 & & 1.35 & 1.87 & & 10.07 & 12.33 & & 1.0 & 11.82 \\
\hline
\end{tabular}


Phosphorous balance was higher where poultry litter was applied at $3 \mathrm{t} \mathrm{ha} \mathrm{a}^{-1}$ basis either with STB or IPNS based compared to sole applied chemical fertilizer. But in case of K, it was evident that $\mathrm{K}$ uptake by the crop is far exceeded than that was replenished from fertilization. Sulphur also showed a positive nutrient balance in all poultry manure applied treatments which are in agreement with the findings of Haque et al. (2001).

\section{Economic analysis}

The application of poultry manure either with IPNS or $50 \%$ STB based chemical fertilizer increased gross and net return than sole application of STB chemical fertilizer (Table 4).
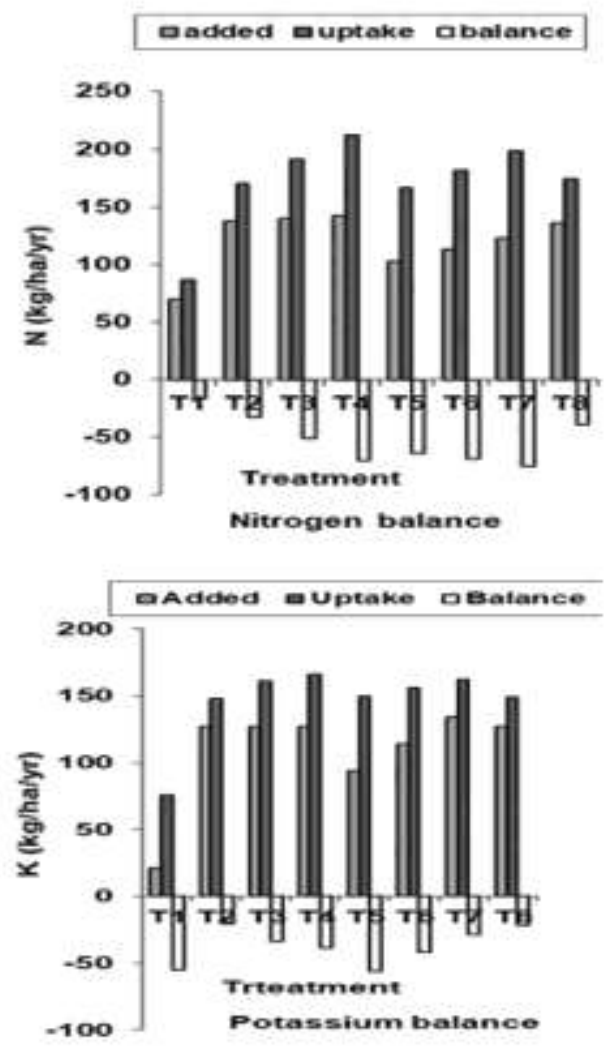

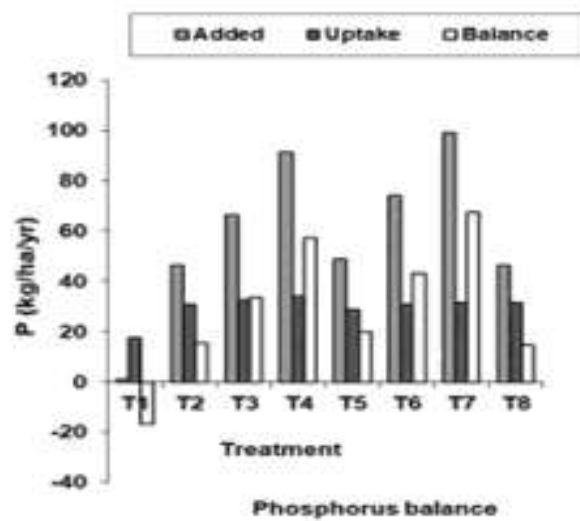

The highest gross and net return was obtained in the treatment $\mathrm{T}_{7}$ where PM was applied @ 3 $\mathrm{t} \mathrm{ha}^{-1}$ with $50 \%$ STB chemical fertilizer followed by the treatment $\mathrm{T}_{3}$ and $\mathrm{T}_{4}$ where PM was applied @ 2 and $3 \mathrm{t}$ ha- ${ }^{-1}$ with IPNS based chemical fertilizer respectively (Table 4). Among the PM treatment the lowest net return was obtained from PM $1 \mathrm{t} \mathrm{ha}^{-1}$ with IPNS based chemical fertilizer. But the MBCR was highest (4.82) in the treatment $\mathrm{T}_{4}$ where $3 \mathrm{t} \mathrm{ha}^{-1}$ PM plus IPNS based chemical fertilizer were applied followed by $\mathrm{T}_{3}$ i.e. PM $2 \mathrm{t} \mathrm{ha}^{-1}$ with IPNS based chemical fertilizer (4.71). Almost similar result was found by Rahman et al., (2009).

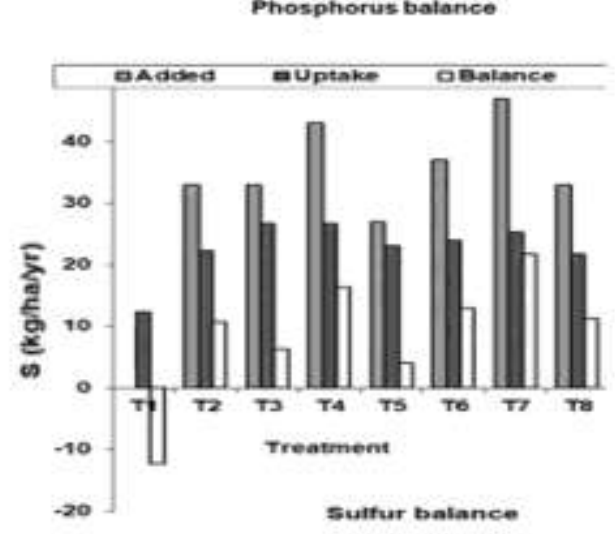

Fig. 1. Integrated use of poultry manure and chemical fertilizers on the apparent nutrient balance of rice. BRRI, Gazipur, 2009-10 (Average of two years). 
Table 4. Integrated use of poultry manure and chemical fertilizers on marginal benefit-cost ratio of rice. BRRI, Gazipur 2009-10 (Average of two years).

\begin{tabular}{cccccccc}
\hline & \multicolumn{2}{c}{ Yield $\left(\mathrm{t} \mathrm{ha}^{-1}\right)$} & \multicolumn{2}{c}{ TVC } & \multicolumn{2}{c}{ Return $\left(\mathrm{Tk} \mathrm{ha}^{-1}\right)$} \\
Treatment & GY & SY & $\left(\right.$ Tk ha $\left.^{-1}\right)$ & Gross & Added & Net & MBCR \\
\hline $\mathrm{T}_{1}$ & 5.33 & 6.23 & 0 & 92410 & - & 92410 & - \\
$\mathrm{T}_{2}$ & 9.06 & 11.14 & 18003 & 158180 & 65770 & 140177 & 3.65 \\
$\mathrm{~T}_{3}$ & 9.57 & 11.90 & 15919 & 167350 & 74940 & 151431 & 4.71 \\
$\mathrm{~T}_{4}$ & 9.45 & 11.93 & 15193 & 165610 & 73200 & 150417 & 4.82 \\
$\mathrm{~T}_{5}$ & 8.89 & 10.51 & 14132 & 154370 & 61960 & 140238 & 4.38 \\
$\mathrm{~T}_{6}$ & 9.30 & 11.12 & 15405 & 161740 & 69330 & 146335 & 4.50 \\
$\mathrm{~T}_{7}$ & 9.67 & 11.61 & 16666 & 168270 & 75860 & 151604 & 4.55 \\
$\mathrm{~T}_{8}$ & 9.16 & 11.38 & 24711 & 160160 & 67750 & 135449 & 2.74
\end{tabular}

Note: Price: Rice grain $=\mathrm{Tk} 15 \mathrm{~kg}^{-1}$ and Rice straw $=\mathrm{Tk} 1.5 \mathrm{~kg}^{-1}$, Cost of poultry litter $1000 \mathrm{Tk} \mathrm{t}^{-1}$. Chemical fertilizer applied as Urea, TSP, MP and Gypsum. Fertilizer cost: Urea $=$ Tk $10.00 \mathrm{~kg}^{-1}, \mathrm{TSP}=\mathrm{Tk} 40.00 \mathrm{~kg}^{-1}$, MP= Tk $35.00 \mathrm{~kg}^{-1}$, Gypsum= Tk

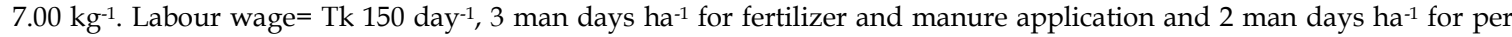
ton additional products including by products.

\section{Nutrient status of the post-harvest soil}

Different nutrients in the post-harvest soil increased slightly with the application of PM in the experimental plots. Irrespective of rate of poultry manure, the percent organic carbon and nitrogen were increased insignificantly in the plots compared to control plot (Table 5). Zaman et al., (2002) reported that the organic matter and residual $\mathrm{N}$ remaining in the soil was greater with poultry manure than with chemical fertilizer. The soil available $\mathrm{P}$ was increased significantly after application of $3 \mathrm{t}$ ha-1 PM in the soil over control. Hossain et al., (2010) found that nitrogen based manure or compost application resulted in available soil $\mathrm{P}$ levels that were significantly greater than those for the P-based manure or compost application. Similar trend was also obtained in case of other available nutrients in the post harvest soil.

Table 5. Nutrient status of the post-harvest soil influenced by poultry manure with chemical fertilizer.

\begin{tabular}{ccccc}
\hline Treatment & OC $(\%)$ & Total N (\%) & Available P (ppm) & Exch. K (meq/100g soil) \\
\hline $\mathrm{T}_{1}$ & 1.49 & 0.14 & 5.91 & 0.24 \\
$\mathrm{~T}_{2}$ & 1.63 & 0.16 & 7.67 & 0.25 \\
$\mathrm{~T}_{3}$ & 1.64 & 0.16 & 10.08 & 0.25 \\
$\mathrm{~T}_{4}$ & 1.69 & 0.17 & 11.33 & 0.25 \\
$\mathrm{~T}_{5}$ & 1.57 & 0.15 & 6.68 & 0.25 \\
$\mathrm{~T}_{6}$ & 1.62 & 0.16 & 7.67 & 0.26 \\
$\mathrm{~T}_{7}$ & 1.68 & 0.16 & 10.67 & 0.25 \\
$\mathrm{~T}_{8}$ & 1.52 & 0.15 & 6.18 & 0.25 \\
LSD (0.05) & 0.039 & 0.010 & 1.23 & 0.029 \\
Initial soil nutrients & 1.40 & 0.14 & 5.77 & 0.14 \\
\hline
\end{tabular}




\section{CONCLUSION}

From the above findings it appears that PM @ $2 \mathrm{t} \mathrm{ha}^{-1}$ with IPNS based chemical fertilizer dose or PM @ $3 \mathrm{t} \mathrm{ha}^{-1}$ with 50\% chemical fertilizer dose may be the suitable combination for obtaining higher grain yield of BRRI dhan29 in wetland Boro rice culture. Some residual effect of PM was also observed in the succeeding T. Aman rice. A positive nutrient balance of $\mathrm{P}$ and $\mathrm{S}$ was observed in the combined use of poultry manure and chemical fertilizer treated plots but other nutrients like $\mathrm{N}$ and $\mathrm{K}$ remained in negative balance.

\section{REFERENCES}

Ali, M E, M R Islam and M Jahiruddin. 2009. Effect of integrated use of organic manures with chemical fertilizers in the Rice-Rice cropping pattern and its impact on soil health. Bangladesh J. Agril. Res. 34(1): 81-90.

Griffin, T S, C W Honecutt and Z He. 2003. Changes in soil phosphorous from manure application. Soil Science Soc. Am. J. 67:645-653.

Haque, M Q, M H Rahman, F Islam, J Rijpma and M M Kadir. 2001. Integrated nutrient management in relation to soil fertility and yield sustainability under wheat-mung-T. Aman cropping pattern. Online J. Biol. Sci. 1(8): 731-734.

Hossain, A T M S, F Rahman, P K Saha and A R M Solaiman. 2010. Effect of different aged poultry litter on the yield and nutrient balance in Boro rice cultivation Bangladesh J. Agril. Res. 35(3): 497-505.
Mahajan, A and R Sharma. 2005. Integrated nutrient management (INM) system- Concept, need and future strategy. Agrobios Newsletter, 4 (3), 29-32.

Mahajan, A, A K Choudhary and R M Bhagat. 2002. Integrated plant nutrient management (IPNM) system for sustainability in cereal based cropping system. Indian Farmer's Digest, 35 (7), 29-32.

Miah, M A M, M Ishaque and P K Saha. 2006. Integrated nutrient management for improving soil health and rice production. Proc. Twenty first BRRI- DAE Joint Workshop on Bridging the Rice Yield Gap for Food Security. BRRI, Gazipur, Bangladesh, 19-21 September 2006. 11, pp. 1-15.

Miah, M A M. 2006. Completion report on integrated soil fertility and fertilizer management for rice based cropping systems 1999-2000 to 2004-2005. Soil Science Division, BRRI, Gazipur, June 2006. p. 128.

Rahman, F, A T M S Hossain, M Akter and R Khanam. 2009. Effect of different aged poultry litter on growth yield and economics of wetland Boro rice. Eco-friendly Agril. J. 2(11): 920-925.

Rijpma, J and M Jahiruddin. 2004. Final report on national strategy and plan for use of soil nutrient balance in Bangladesh.

Saha, P K, A T M S Hossain, U A Naher and M A Saleque. 2004. Nutrient composition of some manure and crop residues. Bangladesh J. Agril. Res. 29(1): 165-168.

Singh, M, V P Sammi and K Reddy. 2001. Effect of integrated use of fertilizer nitrogen and farmyard manure on transformation of $\mathrm{N}, \mathrm{K}$ and $\mathrm{S}$ and productivity of rice-wheat system on a Vertisol. J. Indian Soc. Soil Sci. 49: 430-435.

Zaman, S K, G M Panaullah, M Jahiruddin, M H Mian and M R Islam. 2002. Integrated nutrient management for sustainable yield in Rice-Rice cropping systems. Paper was presented in $17^{\text {th }}$ WCSS symposium at Thailand on 14-21 August 2002. 